\title{
Morfologi Telur dan Larva 2 Ascaridia galli pada Ayam Kampung
}

\author{
Morfology of Ascaridia galli Egg and Larvae 2 in Domestic Chickens
}

\author{
Wida Wahidah Mubarokah ${ }^{1}$, Joko Daryatmo ${ }^{1}$, Budi Purwo Widiarso ${ }^{1}$, Priyo Sambodo ${ }^{2 *}$ \\ ${ }^{1}$ Politeknik Pembangunan Pertanian Yogyakarta-Magelang, Jl. Magelang-Kopeng Km 7 Purwosari \\ Tegalrejo Magelang 56192; \\ ${ }^{2}$ Fakultas Peternakan Universitas Papua, Jl. Gunung Salju, Amban, Manokwari, Papua Barat 98314
}

Article history

Accepted: July-24, 2019

Approved: September 13, 2019

* Corresponding author:

E-mail:

drhpriyosambodomsc@gma

il.com

\section{Abstract}

Ascaridia galli (A. galli) is a parasitic nematode that is often found in chickens which causes weight depression and retarded growth, reduced egg production and decreased egg quality. This study aims to determine the morphology of $A$. galli eggs and larvae 2 (L2) in domestic chickens. Worm eggs are obtained from adult worms that infect domestic chickens naturally. Larvae were obtained from culturing worm eggs in vitro at room temperature for 25 days. A total of 100 worm eggs and $10 \mathrm{~L} 2$ were used in this study. Egg measurements included length and width, while larvae included the total length of the larvae carried out with the Axiovision LE software from egg and larvae photographs taken using a light microscope. Data is processed using Microsoft Excel and is presented in the form of mean \pm standard deviation and percent. Results obtained: eggs oval with thick shell, $73.65 \mu \mathrm{m}$ in length and $50.20 \mu \mathrm{m}$ in width. Larva body consists of the head, body and tail. The posterior part consists of the filament, sheath tail and tip of the tail. Larval length is $352.24 \mu \mathrm{m}$.

Keywords: Ascaidia galli, morphology, eggs, larvae, domestic chickens

\section{Pendahuluan}

Ascaridia galli merupakan nematoda parasitik yang sering ditemukan pada unggas termasuk ayam (Susanti dan Prabowo, 2014). Parasit tersebut menyebabkan kerugian berupa penurunan berat badan dan hambatan pertumbuhan, penurunan produksi telur serta penurunan kualitas telur (Zalizar et al., 2007). Meskipun dikenal luas selama berabad-abad memiliki dampak sangat besar pada industri perunggasan, di Indonesia nematoda belum mendapat banyak perhatian sehubungan dengan memahami biologinya. Penelitian yang mendeskripsikan morfologi cacing $A$. galli pada stadium telur dan larva dalam waktu yang bersamaan pada ayam kampung di Indonesia belum pernah dilakukan.

Secara umum informasi tentang morfologi cacing Ascaridia galli dewasa, baik jantan maupun betina, telah banyak disampaikan (Morgan dan Philip, 1953; Ramadan dan Znada, 1992; Ashour, 1994; Kajerova et al., 2004; Hassanain et al., 2009; Tarbiat, 2012). Panjang cacing jantan antara 30-80 mm dengan diameter 0,5-1,2 mm. Sedangkan panjang cacing betina antara 60-120 mm dengan diameter 0,9-1,8 $\mathrm{mm}$ (Levine, 1981). Sedangkan informasi morfologi $A$. galli pada ayam di Indonesia telah dilakukan oleh Fauzi dan Sahara (2013), dimana panjang cacing $A$. galli yang didapat dari ayam kampung adalah jantan 4,2-7,2 $\mathrm{cm}$ betina 3,3-11 cm.

Pada jenis ayam yang lain, informasi morfologi A. galli pada cacing dewasa, fase telur dan fase larva telah dilakukan. Lalchhandama (2010), menyebutkan bahwa setiap telur A. galli berbentuk oval atau hampir polihedral dengan ukuran kurang lebih 80 x 50 $\mu \mathrm{m}$. Ramadan dan Znada (1992), menyampaikan bahwa L2 memiliki panjang 0,3-1,0 mm. Studi ini menjelaskan morfologi telur dan larva $A$. galli pada ayam kampung sehingga diperoleh informasi yang bermanfaat dalam upaya identifikasi suatu spesies cacing sebagai dasar pengendalian penyakit cacingan pada ayam kampung. 


\section{Materi dan Metode \\ Materi}

Materi utama dari penelitian ini adalah 5 ekor ayam kampung positif ascariasis, mikroskop cahaya dan lensa mikroskop, aerator, tabung Erlenmeyer, cawan petri, cutter, $0,62 \% \mathrm{NaCl}$, dan aquadestiliata.

\section{Koleksi dan Pembiakan Telur menjadi L2}

Cacing dikoleksi dari usus halus ayam yang terinfeksi secara alami yang dipotong di Tempat Pemotongan Ayam di Terban, Yogyakarta, Indonesia. Cacing dikoleksi ke dalam beaker glass berisi $0,62 \% \mathrm{NaCl}$. Seluruh cacing dicuci beberapa kali untuk menghilangkan kotoran. Selanjutnya, dipilih cacing betina dengan kriteria tubuh besar dan bagian posterior lurus (Balqis et al., 2009). Sepuluh cacing betina yang telah dikumpulkan dipotong pada bagian posterior dari porus genitalis yaitu batas antara gelap dan terang pada sepertiga bawah tubuh cacing, kemudian telur bersama uterusnya dikeluarkan dengan cara mengurut tubuh cacing (Prastowo dan Ariyadi, 2015).

Telur cacing hasil koleksi dibiakkan secara in vitro melalui inkubasi dengan aerator dalam Erlenmeyer yang mengandung aquadestilata pada suhu kamar selama 25 hari sehingga diperoleh L2 (Mubarokah et al., 2019).

Pengamatan dan Pengukuran Telur dan L2

Sebanyak 100 telur cacing dan 10 L2 digunakan dalam penelitian ini. Pengamatan telur meliputi bentuk dan tebal-tipis dinding telur sedangkan pengamatan L2 meliputi bentuk dan keadaan posterior L2. Pengukuran telur meliputi panjang dan lebar (Lalchhandama, 2010), sedangkan larva meliputi panjang total larva 2 (Ramadan dan Znada, 1992). Pengukuran dilakukan dengan software Axiovision LE (versi Rel 4.4, Carl Zeiss Vision GmbH, Aalen, Jerman) dari foto hasil pemotretan telur dan larva menggunakan mikroskop cahaya (Olympus BX51, Tokyo, Japan dengan Olympus DP12 camera, Tokyo, Japan) (Sambodo et al., 2018).

Pengukuran panjang telur dilakukan dengan menarik garis imajiner dari ujung ke ujung pada bagian terpanjang dari telur, sedangkan pengukuran lebar telur dilakukan dengan menarik garis imajiner dari ujung ke ujung sisi telur. Pengukuran panjang total larva 2 dilakukan dengan menarik garis imajiner dari ujung anterior ke ujung posterior tubuh larva. Satuan pengukuran dalam mikrometer.

\section{Analisis Data}

Data diproses menggunakan Microsoft Excel. Data disajikan dalam bentuk rerata \pm simpangan baku dan persen.

\section{Hasil dan Pembahasan}

Pada Gambar 1 dapat dilihat bahwa telur A. galli berbentuk oval dan memiliki dinding yang tebal. Bentuk ini sama dengan penelitian sebelumnya yang menyebutkan bahwa telur $A$. galli berbentuk oval dan dilindungi oleh 3 lapisan: bagian dalam yaitu lapisan permeabel disebut membrana vitelin, bagian tengah berupa lapisan cangkang resisten yang tebal, dan bagian luar berupa lapisan albuminosa yang tipis (Ackert 1931; Hansen dan Terhaar, 1956, Tanveer et al., 2015). Fioretti et al. (2005) menyatakan bahwa ciri telur A. galli adalah berbentuk oval, cangkang halus dan berukuran 75 x $30 \mu \mathrm{m}$.

Secara umum, Ramadan dan Znada (1992) membagi perkembangan telur $A$. galli menjadi 8 tahap, yaitu: telur fertil, tahap pembelahan telur, morula dengan blastomer besar, morula dengan blastomer kecil, tahap awal diferensiasi, tahap "tad pole", embrio bentuk awal dan embrio melingkar.

Perbandingan ukuran telur dan panjang L2 antara penelitian ini dan penelitian sebelumnya dapat dilihat pada Tabel 1. Bentuk telur dan L2 dapat dilihat pada Gambar 1.

Panjang telur pada penelitian ini $(73,65 \mathrm{x}$ $50,20 \mu \mathrm{m})$ lebih pendek dibandingkan hasil penelitian sebelumnya $(80$ x $50 \mu \mathrm{m})$ yang dilakukan oleh Lalchhandama (2010). Perbedaan ini diyakini disebabkan oleh perbedaan jumlah cacing dewasa yang digunakan sebagai sumber untuk memperoleh telur, dimana pada penelitian Lalchhandama (2010), telur yang diukur hanya diperoleh dari 1 cacing dewasa. Cunliffe dan Crofton (1953) menyatakan bahwa perbedaan ukuran telur mungkin disebabkan oleh perbedaan jumlah cacing yang digunakan sebagai sumber koleksi telur yang diukur. Selain itu perbedaan ini juga mungkin dipengaruhi oleh perbedaan suhu dan kelembaban daerah pengambilan sampel. Tarbiat (2012) menyatakan bahwa 
perkembangan telur $A$. galli dipengaruhi oleh lingkungan (suhu dan kelembaban).

Larva terdiri atas kepala, badan dan ekor. Bagian posterior terdiri atas filamen, selubung ekor dan ujung ekor (Gambar 2). Borgsteede dan Hendriks (1974) menggambarkan bahwa larva infektif nematoda terdiri atas kepala (ektremitas anterior), badan dan ekor (ektremitas posterior). Bagian ektremitas posterior terdiri atas filamen, selubung ekor dan ujung ekor.

Tabel 1. Perbandingan ukuran telur dan larva 2

\begin{tabular}{lcccc}
\hline \multicolumn{2}{c}{ Peneliti } & \multicolumn{1}{c}{ Telur $(\boldsymbol{\mu m})$} & Larva 2 $(\boldsymbol{\mu m})$ & Lokasi \\
\hline $\begin{array}{l}\text { Mubarokah et al (2019) } \\
\text { penelitian ini) }\end{array}$ & (Hasil & $73,65 \times 50,20$ & 352,24 & Indonesia \\
Lalchhandama (2010) & & $80 \times 50$ & -- & India \\
Ramadan dan Znada (1992) & & -- & $300-1000$ (rerata 800) & Saudi Arabia \\
\hline
\end{tabular}
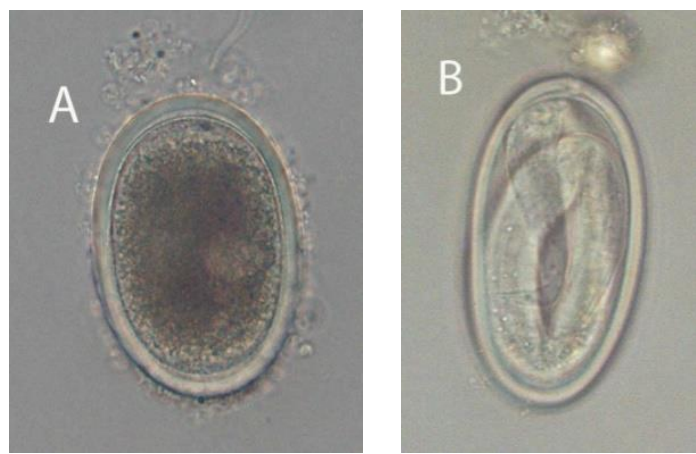

Gambar 1. Telur A. galli. (A) telur fertil, (B) telur berembrio



Gambar 2. Larva 2 A. galli. (a) filamen, (b) perpanjangan selubung ekor, (c) ujung ekor

Panjang L2 pada penelitian ini $(352,24$ $\mu \mathrm{m})$ sama dengan hasil penelitian Ramadan dan Znada (1992) yang menyebutkan bahwa panjang L2 A. galli pada ayam broiler Ross berkisar antara 300-1000 $\mu \mathrm{m}$. Ramadan dan Znada (1992) menyatakan bahwa perbedaan ukuran cacing mungkin disebabkan oleh perbedaan kerentanan jenis ayam.

\section{Kesimpulan}

Hasil penelitian ini menyimpulkan bahwa telur A. galli berbentuk oval dan memiliki dinding yang tebal dengan ukuran 73,65 x $50,20 \mu \mathrm{m}$. Larva terdiri atas kepala (ekrtremitas anterior), badan dan ekor (ekstremitas posterior) dengan panjang 352,24 $\mu \mathrm{m}$. 


\section{Daftar Pustaka}

Ackert, J. 1931. The morphology and life history of the fowl nematode Ascaridia lineata (Schneider). Parasitol. 23(3): 360379.

Ashour, A. A. 1994. Scanning electron microscopy of Ascaridia galli (Schrank, 1788), Freeborn, 1923 and A. columbae (Linstow, 1903). J Egyp Soc Parasitol. 24(2): 349-355.

Balqis, U., Darmawi, Hambal, M. dan Tiuria, R. 2009. Perkembangan telur infektif Ascaridia galli melalui kultur in vitro. $J$ Ked Hewan. 3(2): 227-233.

Borgsteede, F.H.M. dan Hendriks, J. 1974. Identication of infective larvae of gastrointesinal nematodes in cattle. Tijdschrift Diergeneeskunde. 99: 103-113.

Cunliffe, G., dan Crofton, H.D. 1953. Egg sizes and differential egg counts in relation to sheep nematodes. Parasitol. 43(3-4): 275-86.

Fauzi, N.I. dan Sahara, A. 2013. Perbandingan infeksi dan morfologi Ascaridia galli pada ayam kampung (Gallus gallus domesticus) dan burung merpati (Columba livia). Skipsi.

http://etd.ugm.ac.id/index.php?mod=peneli tian_deta...

Fioretti, DP, Veronesi, F, Diaferia, M, Franciosini, MP, dan Proiett, PC. 2005. Ascaridia galli:a report of erratic migration. Ital.J.Anim.Sci.4(1): 310-312.

Hansen, M. F. dan Terhaar, C. J. 1956. Importance of the egg shell of Ascaridia galli to the infectivity of its larva. $J$ Parasitol. 42(2): 122-125.

Hassanain, M.A., Rahman, A., dan Khalil, F.A. 2009. New scanning electron microscopy look of Ascaridia galli (Schrank, 1788) adult worm and its biological control. Res J Parasitol. 4(4): 94-104.

Kajerova, V., Barus, V., dan Literak, L. 2004. Nematodes from the genus Ascaridia parasitizing psittaciform birds: a review and determination key. departement of biology and wildlife disease, University of Veterinary and Pharmaceutical Science, Brno, Czech Republic. Vet Med Czech. 49(6): 217-223.
Kumsa B, Tolera A, dan Abebe R 2008: Vulvar Morphology and Sympatry of Haemonchus Species in Naturally Infected Sheep and Goats of Ogaden Region, Eastern Ethiopia. Veterinarski arhiv. 78(4): 331-342.

Lalchhandama, K. 2010. On the structure of Ascaridia galli the roundworm of domestic fowl. Sci Vis. 10(1) : 20-30.

Levine, N. D. 1981. Buku pelajaran parasitologi veteriner. Gadjah Mada University Press. Yogyakarta.

Morgan, B.B. dan Philip, A. W. 1953. Veterinary Helminthology. USA: Burgess Publicing Company. Hal. 283-286.

Mubarokah, W.W., Kurniasih, Nurcahyo, W. dan Prastowo, J. 2019. In vitro development of Ascaridia galli eggs into infective eggs and larvae of stadium 2 (L2). J Ked Hewan. 13(1):15-18.

Prastowo, J. dan Ariyadi, B. 2015. Pengaruh infeksi cacing Ascaridia galli terhadap gambaran darah dan elektrolit ayam kampung (Gallus domesticus). J. Med. Vet. 9(1): 12-17.

Ramadan, H. H., dan Znada Abou, N. Y. 1992. Some pathological and biochemical studies on experimental ascaridiasis in chickens. Die Nahrung. 35:71-84.

Sambodo, P., Prastowo, J., Indarjulianto, S. dan Kurniasih. 2018. Morphology and morphometry of Haemonchus contortus in goats in Yogyakarta, Indonesia. J Ked Hewan. 12(3):62-65.

Susanti, A.E. and Prabowo, A. 2014. The potential of pinang (Areca catechu) as an anthelmintic for livestock. Proceedings of the National Seminar on Environmentally Friendly Agriculture Supporting Bioindustry in Palembang Sub-Optimal Land. September 16th 2014.

Tanveer, S, Ahad, S, dan Chisti, MZ. 2015. Morphological characterization of namatodes of the genera Capillaria, Acuaria, Amidostomum, Streptocara, Heterakis, dan Ascaridia isolated from intestine and gizzard of domestic birds from different regions of the temperate Khasmir valley. J Parasit Dis. 39(4): 745760 . 
Tarbiat, B. 2012. Environmental tolerance of the free-living stages of the poultry roundworm (Ascaridia galli). Department of Biomedical Sciences and veterinary Public Health. Swedish University of Agricultural Sciences.
Zalizar L, Fadjar. S, Risa. T, dan Dewi AA. 2007. Respon ayam yang mempunyai pengalaman infeksi Ascaridia galli terhadap infeksi ulang dan implikasinya terhadap produktivitas dan kualitas telur. Anim Prod J Prod Tern. 9(2): 92-98. 